\title{
Agri market Marketing Communication Strategy through agriculture-based Online Shopping Application
}

\author{
Lita Wulantika ${ }^{1}$, Lasmaria F Simarmata ${ }^{2}$ \\ \{lita.wilantika@email.unikom.ac.id ${ }^{1}$, lasmariafs@mahasiswa.unikom.ac.id² $\}$ \\ Department of Management, Universitas Komputer Indonesia, Indonesia ${ }^{1}$ \\ Department of Communication Science, Universitas Komputer Indonesia, Indonesia ${ }^{2}$.
}

\begin{abstract}
This study aims to find out the communication marketing strategy form through one of the agriculture-based online shopping applications. This study used a qualitative approach. The descriptive research method with the data collection techniques is literature study and online data search. Then it is analyzed according to the descriptive method. This research is done by discussing the current marketing communication strategies by utilizing technology, paying attention to market share and consumer needs which are the important points in online Agri market business; with an agriculture-based online shopping application, it can make marketing easier and get customers. The result of this research is to identify whether the online Agri market has a good promotional strategy and can compete with other online shopping applications that have different bases. Along with technological advances, the online Agri market improves the quality of sales and purchases of fresh agricultural products from producers to consumers.
\end{abstract}

Keywords : Marketing strategy, Agri market business, Agricultural Product

\section{Introduction}

According to Kotler and Keller, marketing communication is a means of companies to provide information, persuade (persuasion), and remind consumers directly or indirectly about the products and brands that companies sell [1]. In the era of technological advances, marketing is not carried out longer conventionally but rather uses new media (Internet), which is commonly called e-commerce. According to E S Soegoto, in increasing shopping trends, online businesses see online trends that are then implemented by e-commerce systems [2]. Rowley states that in a world with digital progress, marketing communication is closely related to creating a presence, creating a relationship and creating reciprocal value using the Internet as an interactive marketing channel. Combine marketing communication with commercial transactions that can 
be accessed anywhere [3]. This is also supported by the research from Peltier, Schibrowsky, and Schultz in their research on Interactive Integrated Marketing Communication that companies must develop the ways to create information communication strategies in deep marketing using new media to interact with consumers [4]. Likewise, the research results were conducted by Eisingerich and Kretschmer. It concluded that there are several effective ways to increase online sales through customer loyalty, including personalized shopping, clear categorization, order tracking, and detailed product/service information [5]. Subsequent research that is also the reference of this research is from Štefko, Királová \& Mudrík, which discusses marketing communication strategies from historical tourism sites. This research is more specifically discussing the tools of marketing communication and looking for correlations between communication strategies that are carried out with the image of the tourism place [6].

Meanwhile, Kim and Fesenmaier describe in their research that six dimensions to determine the further from a travel website can generate a good image of itself to the user, namely informativeness, usability, credibility, inspiration, involvement, and reciprocity. This positive image will later increase sales. Then, in marketing tactics in the New Wave Marketing era, the marketing mix concept consisting of Product, Price, Place, Promotion (4P) [7]. Rábová in his research states that communication strategies can be analyzed from two views, namely how a company builds its brand identity through the media that they choose and how they make a difference (if any) with the company's direct competitors. This research focuses on the presentation of marketing in small and medium enterprises (SMEs), especially in the cosmetics industry [8]. Meanwhile, Zaušková, Bezáková \& Grib discuss marketing communication in the linear process of environmental innovation and implement a part of it in small and mediumsized businesses in the Slovak business environment. The company also cannot ignore consumers who focus on marketing communication strategies that are carried out to satisfy customers to provide alternative organic products for conventional products. The results show the importance of marketing communications which are brought by innovators, as well as to customers [9]. In the research of Chen \& Xie, analyzing product reviews by online consumers has an essential role in consumer purchasing decisions. Product reviews based on personal experience can be a new tool in marketing communication that is useful as a sales assistant to identify products according to its idiosyncratic conditions [10,11].

This research aims to find out the marketing strategy of Agri market marketing through one of the agricultural-based online shopping applications. This study used a qualitative approach with descriptive research methods, and the data collection techniques are literature studies and online data search, then it is analyzed according to the descriptive method. This research is done by discussing the current marketing communication strategies by utilizing technology, paying attention to market share and consumer needs which are the critical points in the online Agri market business. The result of this research is to identify whether online Agri market has a good promotional strategy and can compete with other online shopping applications that have different bases. Along with technological advances, online Agri market improves the quality of sales and purchases of fresh agricultural products from producers to consumers.

\section{Material and Methods}

This study used a descriptive method with a qualitative approach to determine variables that are related to marketing communication strategies by using agricultural-based online shopping applications. The agriculture-based online shopping application in this research is Vegbagicha. The data collection techniques are literature study and online data search which will be analyzed according to the descriptive method. This study also used previous research studies to analyze 
marketing communication strategies in marketing their products by using online shopping applications based on agriculture.

\section{Results and Discussion}

In the era of technological development, increasing rates of human mobility have also increased significantly. This requires the world of trade to be able to provide services and goods quickly by consumer demand even in the case of Agriculture. To overcome this, a new transaction method appears that uses internet media to connect producers and consumers (E-commerce). Vegbagicha is one of the E-commerce Agri markets that serves as a trading transaction platform between Consumers to Consumers (C2C).

Agri market marketing communication strategy using an agricultural-based shopping application that is Vegbagicha can be viewed using the marketing mix concept consisting of Product, Price, Place, Promotion (4P):

a. The product can be seen in the form of physical goods or services that are offered. Strategies in terms of products can be in the form of product diversity, product quality, product design, features, brand names from products to packaging sales and others. This can be seen in the Vegbagicha Application (Fig. 1).

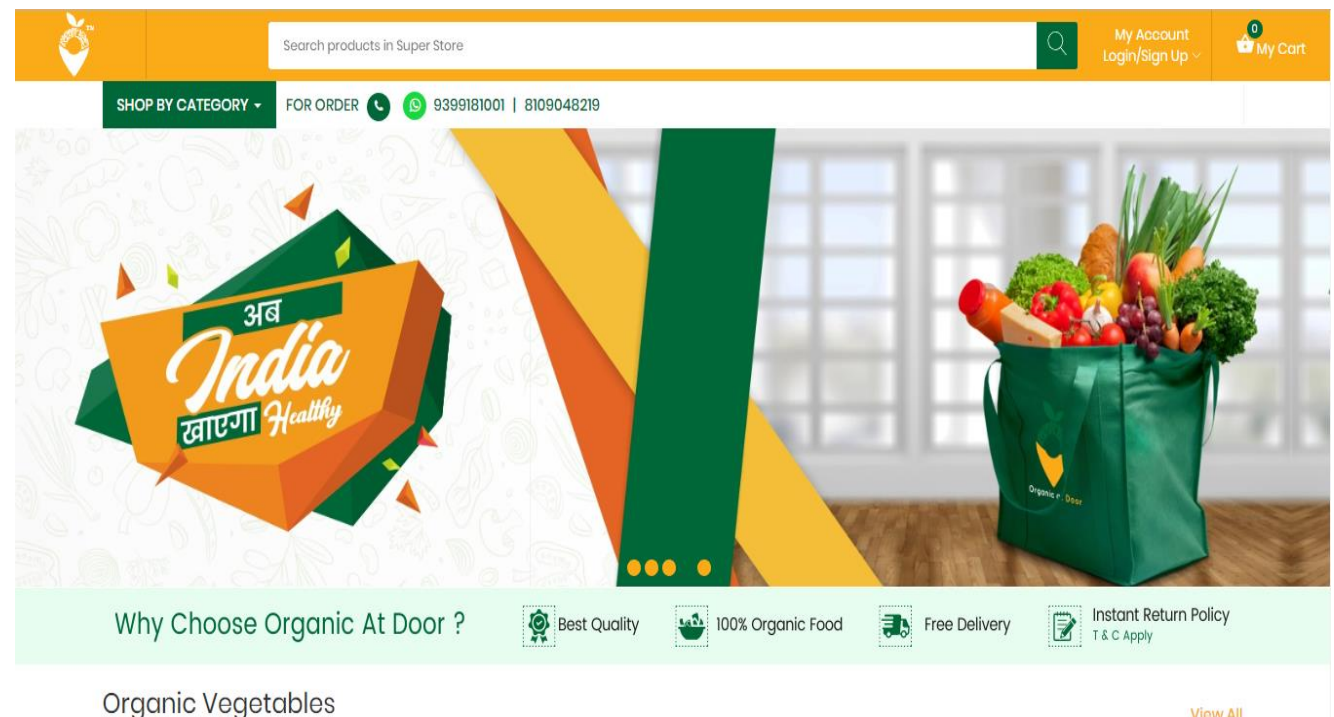

Organic Vegetables

Fig 1. Front View Application with Various Categories That Are Offered. This Figure was adapted from https://www.organicatdoor.com/ on August 8, 2018.

Each of these categories has various types of fresh products that come directly from farmers who collaborate with the Vegbagicha application (Fig. 2). 


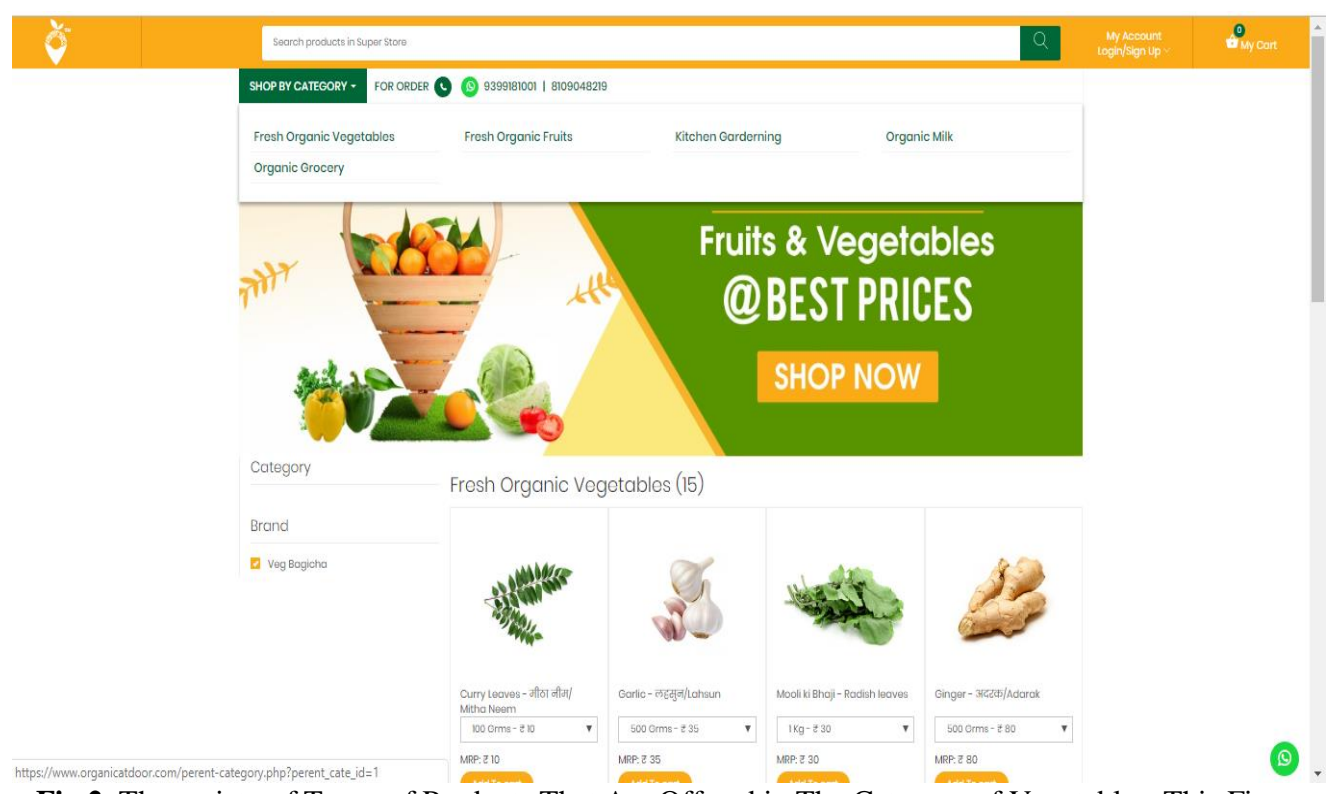

Fig 2. The variety of Types of Products That Are Offered in The Category of Vegetables. This Figure was adapted from https://www.organicatdoor.com/ on August 8, 2018.

It provides benefits for consumers, namely being able to choose which products they want to consume directly with good quality quickly without the hassle of going to markets or supermarkets. In this application, consumers can also choose the packaging of the desired product whether they want to use plastic or no, can choose the estimated time for shipping the order and also can choose the option if the farmer who sells the product experiences a crop failure.

b. Price is one important component in marketing strategy. The price of a product should adjust to the purchasing power of the product target market. Marketing strategies in terms of prices include discounts, allowances, payment terms, credit, and so on. The Vegbagicha application provides a menu for refunds if the consumers are not satisfied with the vegetables they buy. Besides, consumers will get free postage for certain purchases (Fig. 3). 


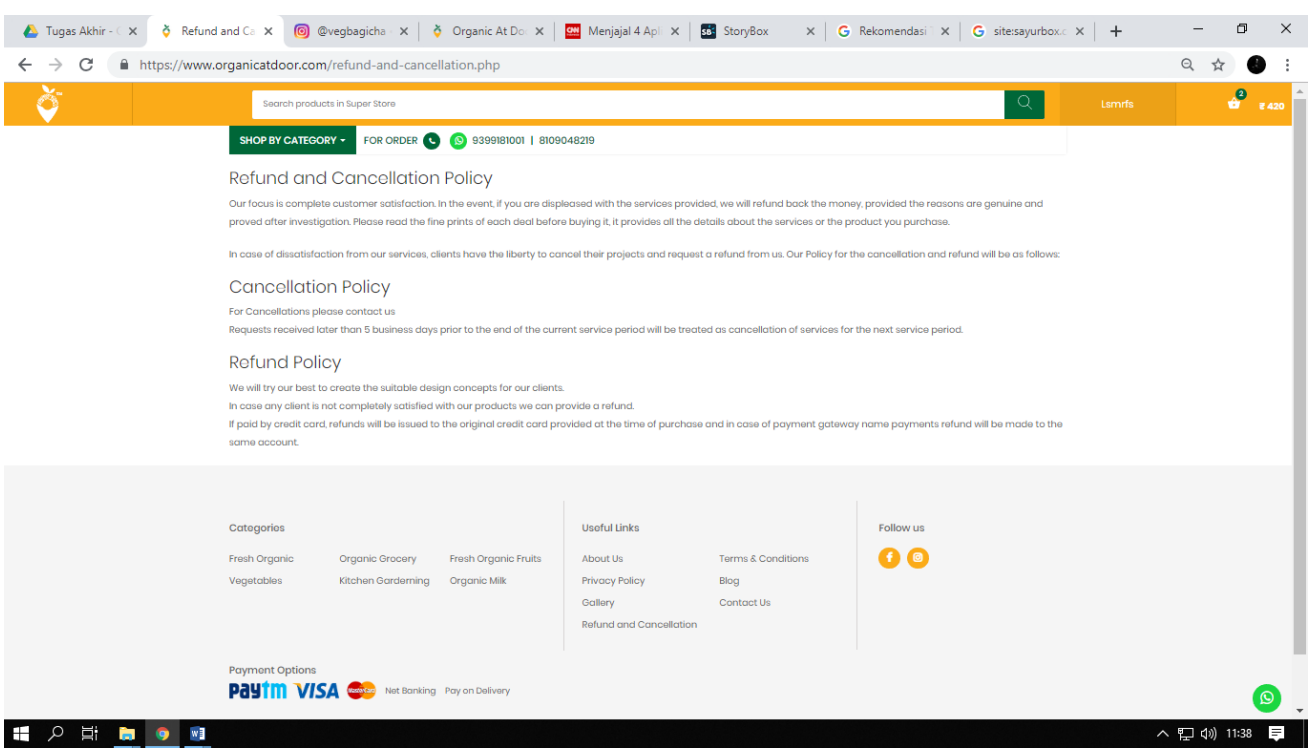

Fig 3. Refund Policy. This Figure was adapted from https://www.organicatdoor.com/ on August 8, 2018.

For the payment method, there are several options available whether to pay with Go-pay or by transfer. This will facilitate consumers without having to bother spending cash, and they can make payments at home by using mobile banking (Fig. 4).
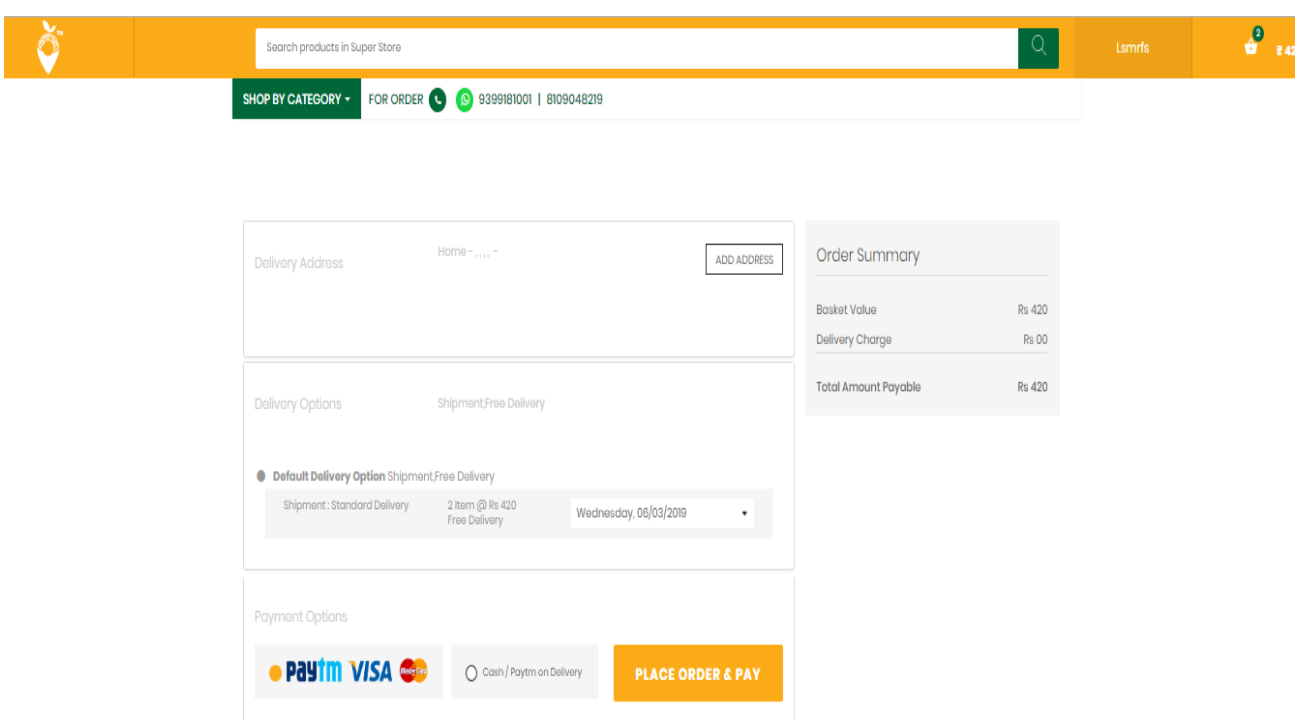

Fig 4. Payment Method. This Figure was adapted from https://www.organicatdoor.com/ on August 8 , 2018. 
c. Place is a place that is used to distribute goods or services to consumers which means consumer access to the products that are sold. Marketing strategies about place include location, distribution channel, wide distribution area, transportation from or to the place, logistics and others. For Vegetable Boxes, they serve to buy and selling only in certain areas, namely Indore, India. For the distribution itself, it is done by the driver that is provided by Vegbagicha so that it becomes safer.

d. Promotion is also an important thing in terms of conveying product information and creating a product image to the public to be able to persuade customers to buy products which are offered. This form of promotion from the Vegbagicha application is using Instagram social media. With eye-catching Instagram content, consumers are interested in the products which are offered (Fig. $5)$.

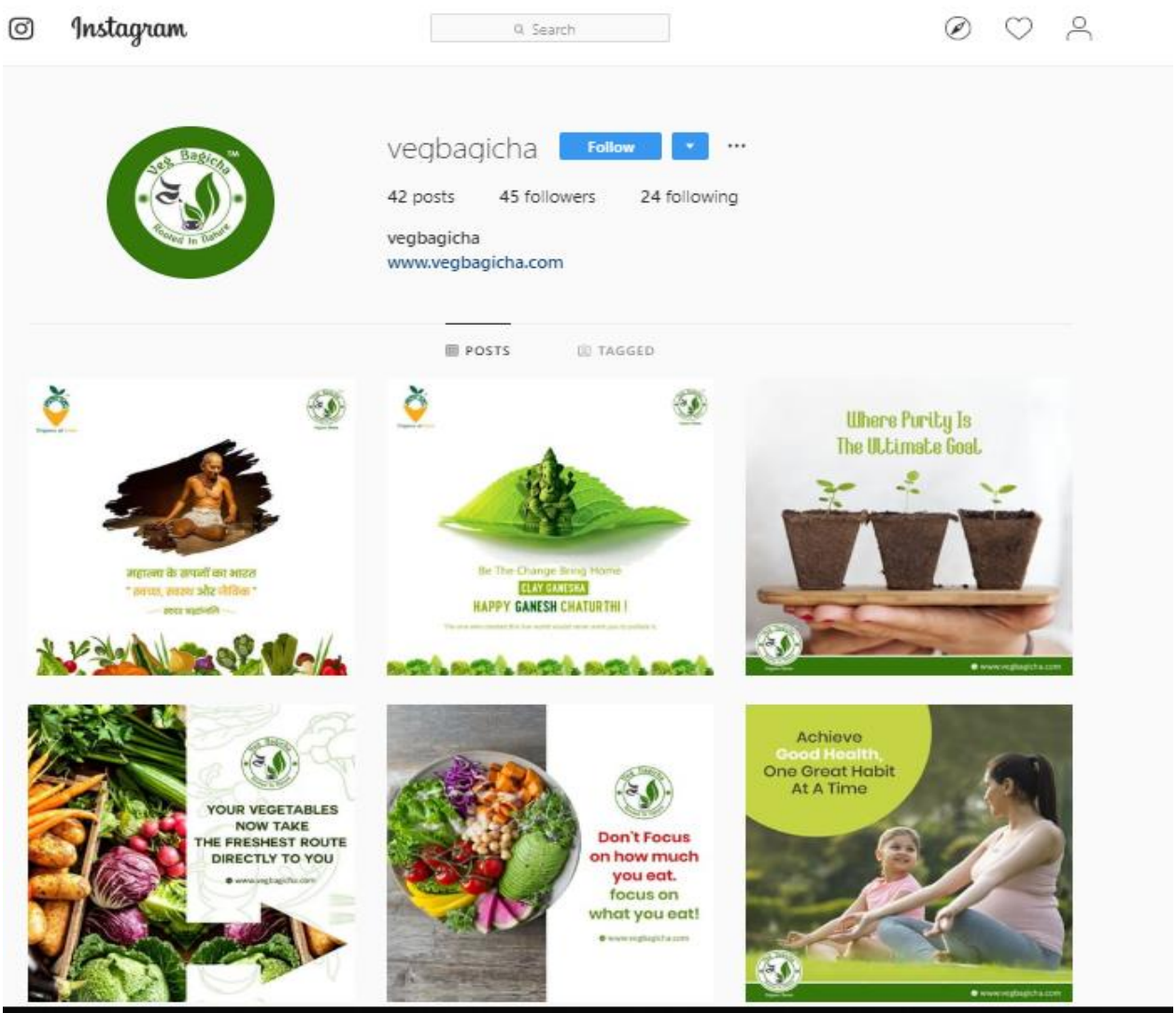

Fig 5. The Example of Vegbagicha Endorsement. This Figure was adapted from www.instragram.com/vegbagicha/ on August 8, 2018.

Four marketing communication strategies are powerful enough to increase sales by using the Vegbagicha online shopping application. The high need with the convenience of the buying and selling method which is offered by Vegbagicha on the four sides above is a consideration for consumer purchasing decisions. 


\section{Conclusion}

The development of technology makes it easy for people, especially while doing online shopping in the field of Agrimarket. They need one application; Vegbagicha, consumers can fulfill their needs quickly and efficiently. The 4P marketing communication strategy (product, price, place, promotion) is made using the Vegbagicha application is a consideration for consumer purchases.

\section{Acknowledgments}

Through the process of guidance, support, and assistance from all people, the researchers can complete this journal. Therefore, the researchers intend to express their gratitude to the Chancellor of the Universitas Komputer Indonesia Assoc. Prof. Dr. Ir. Eddy Soeryanto Soegoto, M.T, for helping to provide the material and the information so that this journal can be completed properly.

\section{References}

[1] Kotler. P, and Keller K. : Marketing management 14th edition. Prentice Hall. (2011)

[2] Soegoto, E. S.: Entrepreneurship Menjadi Pebisnis Ulung. Elex Media Komputindo. (2013).

[3] Rowley, J. :Just another channel? Marketing communications in e-business. Marketing Intelligence \& Planning, 22(1), 24-41. (2004).

[4] Peltier, J. W., Schibrowsky, J. A., \& Schultz, D. E.: Interactive integrated marketing communication: combining the power of IMC, the new media and database marketing. International journal of advertising, 22(1), 93-115. (2003).

[5] Eisingerich, A. B., \& Kretschmer, T.: In e-commerce, more is more. Harvard Business Review, 86(3), 20-21. (2008).

[6] Štefko, R., Királová, A., \& Mudrík, M. :Strategic marketing communication in pilgrimage tourism. Procedia-Social and Behavioral Sciences, 175, 423-430. (2015).

[7] Kim, H., \& Fesenmaier, D. R.: Persuasive design of destination web sites: An analysis of first impression. Journal of Travel research, 47(1), 3-13. (2008).

[8] Rábová, T. K.: Marketing communication of SMEs specialized in cosmetic industry in magazines for women. Procedia-Social and Behavioral Sciences, 175, 48-57. (2015).

[9] Zaušková, A., Bezáková, Z., \& Grib, L.: Marketing Communication in Eco-Innovation Process. Procedia Economics and Finance, 34, 670-675. (2015).

[10] Chen, Y., \& Xie, J. Online consumer review: Word-of-mouth as a new element of marketing communication mix. Management Science, 54(3), 477-491. (2008).

[11] Soegoto, E. S., \& Ardian, F.: Designing E-Learning Application. In IOP Conference Series: Materials Science and Engineering (Vol. 407, No. 1, p. 012002). IOP Publishing. (2018). 